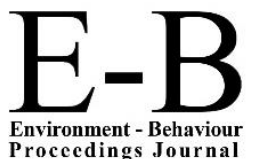

Environment - Behaviour
Procecedings Journal

\section{CSSR 2018}

https://cssr.uitm.edu.my/2018/

5th International Conference on Science and Social Research

Le Meridien Kota Kinabalu Hotel, 5 - 6 December 2018

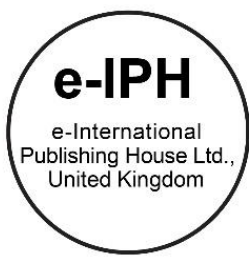

\title{
Imitation of Batik Sarong Design and Features
}

\author{
Afiqah Izzati Sobri, Rafeah Legino \\ Formgiving Research Group, Faculty of Art \& Design, \\ Universiti Teknologi MARA 40450 Shah Alam Selangor, Malaysia \\ fiqah.zzati@gmail.com, rafeahl@uitm.edu.my \\ Tel: +6012-9059800
}

\begin{abstract}
This study aims to discover the imitation batik sarong in term of their design, which includes the motifs, colours and structure. The method is by field visit, observation and interviews. The scenario in the batik industry and detail about the characteristic that fooled consumers was stated in this study. The imitation batik is not a traditional batik sarong, because they are not aesthetically sustained the traditional technique and characteristic is also different. In a future study, this research should define how the role of innovation can continue, and the traditional batik flourishes without shading off the batik tradition.
\end{abstract}

Keywords: Batik, Design, Imitation, Malaysia, Sarong, Traditional, Wax.

eISSN: 2398-4287@ 2020. The Authors. Published for AMER ABRA cE-Bsby e-International Publishing House, Ltd., UK. This is an open access article under the CC BYNC-ND license (http://creativecommons.org/licenses/by-nc-nd/4.0/). Peer-review under responsibility of AMER (Association of Malaysian Environment-Behaviour Researchers), ABRA (Association of Behavioural Researchers on Asians) and cE-Bs (Centre for Environment-Behaviour Studies), Faculty of Architecture, Planning \& Surveying, Universiti Teknologi MARA, Malaysia.

DOI: https://doi.org/10.21834/ebpj.v5iSl3.2539

\subsection{Introduction}

Wax and resist are the main components in the traditional batik making. However, the impact of the technology, imitation batik sarong is now available and became a significant issue in the batik industry, certainly at Kelantan and Terengganu. The term of batik that historically verse was derived from the word 'tik', which means 'to drip' or 'drop' (Dunsmore, 1996). Most studies of batik have been carried out on aesthetic value and techniques. Batik is filled with art formalism characteristic that is admirable as Malay's culture and customs. Batik is also known as a culture and identity transmitter. Batik is a term from an Indonesian-Malay Archipelago that derived from the word 'Ambatik' that is separated into two consonant - 'Amba 'and 'tik'. The word 'ambatik', which translated means 'a cloth with little dots'. It has been revealed by Gatut and Aryanto (2010) when the printing technology invented in 1970; the traditional batik is abundant in the market. These are since the printing technology has imitated the character of traditional batik. Then, the prices for imitated batik was low compared to traditional batik. On the other factor, these are all was part of the business competition, and also impact in the batik industry without considering the philosophical values of batik, descriptive sense and traditional culture as the main essence of the batik art. Within the time consuming of batik making, the demand for batik does not meet the supply of batik. So, the emergence of imitation batik sarong was the alternative for the mass-production of batik. This issue had gained attention when in the local news reported that the development of imitation batik had killed the traditional batik industry and is about the prices. In local news, stated below:

Harga yang jauh lebih murah selain kelihatan hampir sama dengan batik asli menyebabkan ramai pengguna memilih batik tiruan, manakala bagi yang jahil seni batik pula terpedaya menganggap batik tiruan sebagai produk asli. Batik tiruan jejaskan industri batik asli Terengganu, 2012, ๆ 2).

eISSN: 2398-4287C 2020. The Authors. Published for AMER ABRA cE-Bsby e-International Publishing House, Ltd., UK. This is an open access article under the CC BYNC-ND license (http://creativecommons.org/licenses/by-nc-nd/4.0/). Peer-review under responsibility of AMER (Association of Malaysian Environment-Behaviour Researchers), ABRA (Association of Behavioural Researchers on Asians) and cE-Bs (Centre for Environment-Behaviour Studies), Faculty of Architecture, Planning \& Surveying, Universiti Teknologi MARA, Malaysia.

DOI: https://doi.org/10.21834/ebpj.v5iSI3.2539 
The prices are much cheaper other than having a similar design with the traditional batik. However, there are many consumers interested in buying imitation batik sarong while to those who do not aware of the batik aesthetic would fall upon buying the imitation batik.

\subsection{Literature Review}

\subsection{Batik History}

Clothing is an invention, which represents the identity, and the appearance of any individual will show through clothing (Laurie, 1992). This kind of factor had cited by Claudia, Lukman, Piliang, Sunarto. The researcher remembered when the researcher was a child, the researcher's mother used a batik sarong for buaian (swing), to put the baby for a nap. The researcher was also observed when the researcher's late grandmother was at the paddy fields in Kampung Sungai Layar Kedah. She was wearing a batik sarong on their head (look like the head of the cow) and even worn a batik sarong as their bottom when doing their daily work. In Indonesia, men are seen wearing a headdress called blangkon or iket kepala typically a headgear that was made from batik. In this country, traditionally, batik was sold 2.25-metre lengths for kain panjang (long cloth and sarong) pair with the kebaya dress (Steelyana, 2012). Therefore, batik sarong is synonym with the Malay Archipelago that seen in the rural area of Malaysia and Indonesia the usage of batik is in daily life- as a wrap or sarong, or headcloth that wore by men and women.

The word ambatik is from amba and tik, and the meaning is drawn with dots, because of the word of amba means to bring, while tik is titik means dots. The most beautiful batik in Malaysia is from Terengganu. Hussin (2016) mention that Wan Hashim Wan Teh was explaining the definition of batik, and it is origin words from a part of Indonesia Islands. He also cited Arney (1997) asserted that the batik word derived from the ambatik that was initially from the Javanese language. The phrase tik is relatively from titik, which means dot and 'ba' mean doing work actively. However, there are slightly different meaning that was recorded by Hussin (2016) when Nawawi said the word 'tik' is derived from the Malay word of Indonesia means dot while mba is obtained from the Javanese mean 'slave' or 'servants'. Thus, the definition of batik is an activity of drawing the dots very actively. However, people nowadays have misunderstood that the term 'batik' are defining the motif and pattern of batik. Samah (1985) decline that batik is not defining the motifs but the process and the making of batik that has involved the wax resisting. It is a tradition for years. Besides, many batik artist and researchers, discovered that batik has several methods like batik canting and batik block, and other innovative techniques. The traditional batik recognised through their traditional process of batik making. The meaning that linked with the batik methods, as stated in the next segment.

\subsection{Batik Canting/ Tjanting/ Tulis (Hand-drawn)}

This batik's ultimate tool is the Tjanting or canting (stylus tip), which is derived from the Indonesian fellows mean draw. A technique that will give a very mesmerising result with the usage of chanting that made from a bamboo stylus with metal to hold the melting wax. This batik style needs a very high skill in controlling the movement to draw on the motifs (Aziz, 2008; Legino, 2012).

\subsection{Batik Cap/Block}

The batik motifs are usually stylised and adapted from the surrounding. Knowing the Archipelago land is situated in a tropical climate and rich with tropical forest. A study also will show the function of Batik Java in the early years is various. In Indonesia, in the feudal time, batik has been used differently by divided into two casts, which is the royal and the ordinary community. In Indonesia, the different design was able to trace on their pattern. The quality of batik and the functions were changed, either for the formal and essential clothes (Siswandy,1999). Indonesian batik researcher Djoemema (1999) have suggested that there were two parallel traditions in batik, the batik that design for the palace, and also the batik design for the ordinary people. The hierarchy status indicated from the design motifs in certain batik, which worn by the royalties and nobles is also restricted to be worn by the local people (FraserLu, 1988). However, Elliot (2004) said that batik has much other symbolism in culture, and it is also used in rituals, which related to the wayang kulit (traditional shadow puppet) and recognised as a magic cloth with functionality and symbolism. In Malaysia, batik block making practised in few places at Kelantan and Terengganu. Indeed, batik sarong is one of the fabulous creations. Then, the outcome purposely for a local customer in this country (Arney, 1987; Legino et al., 2017).

\subsection{Methods and Technology in Batik}

They are techniques that make the process of batik Malaysia and batik Indonesia was the difference. An interview with Mrs Haniza Hashim (2017), a batik artist and a former architect said that Malaysia's batik sarong that made from stamped of block technique involved a process where the procedure is slightly different from Indonesia. She also stated that the block is made of metals such as copper, brass and iron, which is massive, and they have to splash to get rid the excess of wax that sticks to the block after dipping in hot-melted-wax. After that, the batik maker will stamp on to the cloth. However, the Indonesia technique, which implies the same but slightly different batik maker, does not splash the block to remove the hot-melted-wax but directly stamp on the fabric.

On the other hand, the setting of batik procedure is different, not only the differences on the block stamped, but also their 'kitchen' (where they use to melt the wax into liquid). The kitchen that they are slightly different from the observation, Malaysia's batik kitchen is somewhat shallow depth, meaning that they have a shield around their pot, which is quite higher. However, in Indonesia, they use a standard pot without any protection. The reason why in Malaysia, the wax was melting in a container that has protection; this is because of the batik maker have to splash the excess of the melted wax. Not only the setting is different but also the tools that have been used in making batik sarong is also different. The difference that has determined in the batik design and identity, where the batik 
sarong is not just using block but also using a stylus or canting. There are also using the variety of method that includes both canting or stylus and block stamp to produce a very remarkable design on batik sarong. For instance, Mrs Rosidah Abdullah (2017), a curator from Muzium Tekstil Negara (National Textile Museum) stated that she went to Indonesia and observed how the batik makers produce their batik. She said that why batik Indonesia different from Malaysia, was recognised from their tools and the design process that they implement. The tools that they have widespread use is a canting stylus and has seven tips, compare to Malaysia that only has one tip stylus. Thus, the difference in tools also produces a different kind of design on the batik sarong. Not only just that, but the skills are also needed to handle a different type of tools to make batik sarong. When the tools are different, the skill, and method is different too, and so the design is made differently because of the combination of tools and process.

Another technique of making batik is known using the printing technique. The screen printing consists of three materials or tool: the screen where the stencil of the image, the squeegee, and ink. The screen-printing process uses a silk mesh stretched tightly over a frame made of wood or metal, with proper tension being critical in producing the accurate colour registration. The printing techniques involved the use of materials such as silkscreen frame, special dyes, wax, and white cloth. There are few processed involved in the printing batik using a silkscreen, which is way different from the traditional batik process (Fong and Youwen, 2016) [9].

However, there is a batik that fills the demand for batik sarong nowadays is the imitation batik. The imitation batik is formed of mimicry of batik. The purpose of imitation batik sarong is as the same as the batik sarong traditional. The researcher has worn a personal collection of imitation batik as a sarong. The imitation batik sarong appearance looks like the same as the batik traditional. However, there are distinctive feature and characteristic in the imitation. At one glance, the imitation batik is surprisingly looked as much as the most beautiful batik. The researcher's experience during the field visit to Nysakapas, the owner Mrs Haniza Hashim told the researcher on how to observe the batik authenticity. She added that batik could be recognised by just looking at both side of the surface; the wax was penetrated through the fabric and can be seen on both sides.

This imitation batik was sometimes produced by local or import from nearby countries such as Indonesia and Thailand. In Indonesia, the imitation batik was call as batik sablon. Sablon is an Indonesian word that is an adaptation word from Dutch, which is 'Schablon' in Swedish and Sjabloon in Dutch, which is the same meaning of template and stencil. Sablon is another term for printing technique but is a slightly different usage of pigment or dyes. Sablon was consist of dyes that were mix with rubber and an extender- a chemical or synthetic dyes.

Cetak sablon merupakan kegiatan mencetak yang menggunakan alat dasar layar saringan (screen), dengan kerapatan serat tertentu. Screen ini kemudian diberi model cetakan atau mal yang berasal dari negative desain yang dibuat sebelumnya. Setelah melalui proses penyinaran (exposure), akan terbentuk bagian-bagian yang dapat dilalui dan tidak dapat dilalui oleh tinta. Prosesnya adalah dengan menuangkan tinta di atas screen dan disapu menggunakan rakel yang terbuat dari karet. (Kreasi Cetak Sablon Mudah dan Berkualitas Tinggi Pada Kaos (Luzar, 2010).

The printing sablon was an activity to print using the screen or silkscreen printing on a particular fibre. The screen is then given a model print or stencil that are from a negative design that was prepared before. After going through exposure, the stencil will be formed on the parts that can be dyed. The process that involved is by pouring the dyes on the screen and smothered by squeegee made by rubber.

Luzar (2010) made the statement above mentioned that the batik sablon is made from the process of printing that includes the process and tools of silk screen printings. The rubber in sablon dyes and pigment is durable so that it can bring out bright colours that can be print on many surfaces such as glass, aluminium, wood and plastic. This technique of printing is the same as batik cetak (printing) or batik print that were used in Malaysia in early 1900.

\subsection{Type of Sarong}

Kim (2013) stated that people in Southeast Asia wear the sarong, particularly in Malaysia, Indonesia, Singapore and Brunei. Kim (2013) added the definition of sarong, which is adapted from Malay word sarong, which is mean a 'sheath' or 'covering'. The function of the sarong in the Malaysian community is more than just a hip wrapper. Writing by Hussin, Nawawi and Mohamed (2013) cited Swettenham (1921) explain that kain sarong is used in many ways including bath wear while sleeping, and a shoulder sling and to carry kinds of stuff. The researcher grandmothers once said that batik is so close to Malay. The function is following recycle of a human said that "when a baby is born, the bidan (midwife) welcoming a baby by wrapping the baby in a batik sarong, they sleep in buaian (cradle) that made from batik sarong. The batik sarong is also used when upon death to cover the body and even on the coffin. Similarly, to kain batik Siam, which has the same structure as a sarong. Particularly, kain batik Siam, that was imported from Thailand with a similarity of motif and designs that implemented to the fabrics. Following by the Malaysia Handicraft Development and Corporation stated that:

Terdapat satu lagi teknik yang agak unik iaitu Batik Cetak Sutera Saring atau dikenali sebagai Batik Skrin. Batik Skrin dipercayai telah dipelopori oleh sekumpulan pembuat batik di negeri Kelantan, di mana teknik penggunaannya dikatakan telah dibawa masuk daripada negeri Siam pada awal tahun 1900. (Malaysia Handicraft Development and Corporation).

Another technique is unique that is called silkscreen batik or known as Screen batik. Screen Batik is said to be from a group that was the pioneer in making batik in Kelantan, where the technique is said to be from Siam (Thailand) around early 1900.

So, batik Siam was importing to this country, and this technique is also known as batik screen in Malaysia. Malaysian begun to buy and produce as their cost is cheaper and faster. Even though the method was different and does not involve wax resist, but they sold at high numbers because of its cheapness and the versatile design that look like original batik. The imitation batik sarong from 
Siam also shows that vast and varieties of pattern and motif arrangement. A researcher stated that batik Siam has the same structure and motif design, just like the original batik. He said in his writings that:

Kain batik Siam diistilahkan sebagai kain batik kerana susunan motif-motif batik Siam adalah sama dengan susunan motif-motif batik sarung. Susunan motif-motif batik Siam turut memperlihatkan bahagian-bahagian bunga tubuh, gigi kain, kepala kain, pengapit dan corak gunung. Bunga tubuh ialah corak-corak atau motif-motif yang menghias sebahagian besar dari "tubuh" sesehelai kain. Dua bahagian bunga tubuh dipisahkan oleh kepala kain yang pada kebiasaannya terdiri sama ada dari motif-motif pucuk rebung ataupun bunga pokok. Kepala kain diberi motif-motif kecil pada sebelah kiri dan kanannya secara menegak. Motif-motif tersebut dikenal sebagai pengapit (Keistimewaan Batik, Samah, 1990, ๆ5).

The Siam batik cloth called as kain batik because of the Siam motifs arrangement has the similarity with the motifs in batik sarong. Batik sarong Siam is also using the motifs of flowers and the concept of mountain element. The motifs of flower usually located at the two main parts of the badan kain (the body). Where the two primary body were separated by the kepala kain (the main centre of the sarong) that usually decorated by pucuk rebung (bamboo shoots) and some time with any kind of flower plant. The main centre of the sarong was placed with the small motifs on the right and left side in vertical. Those motifs are known as pengapit (the flanking borders).

\subsection{Methodology}

The methodology is a procedure to define the study into manageable phases. The research objectives and research questions are the first components to get the output in Table 3.1. An explanation below the table is the brief description of Table 3.1 was assuring the problems for this study solved, and few methods that answer the restated research objectives and research questions:

i) What is the characteristic of imitation batik?

ii) Which element and influence the imitation of batik sarong design?

Data collection through a method that stated before, these data then will be sifted and extracted or transcribe to meet the specific goals to answer the research question and the objectives of this research. The data transcribed and categorised into the following table:

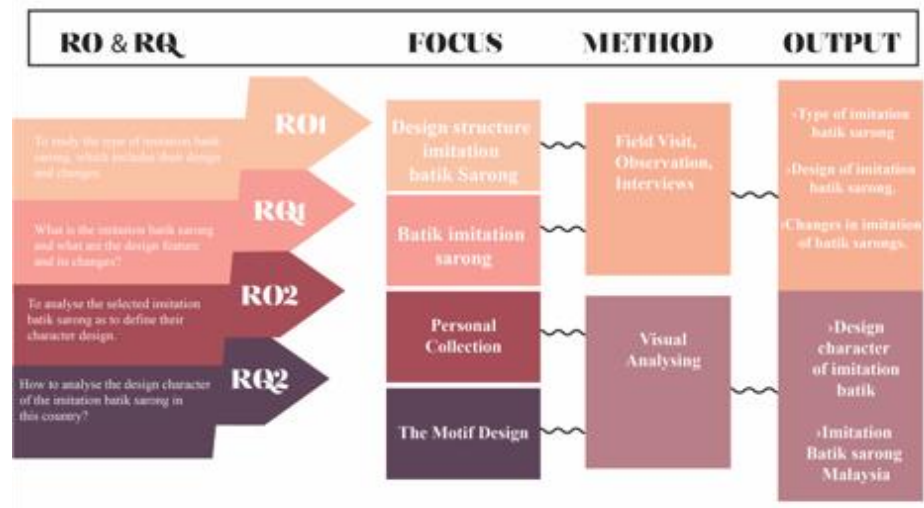

Table 3.1 shows the process of methodology in achieving the output of this research. ( $\mathrm{RO}=$ Research Objectives, $\mathrm{RQ}=$ Research Questions)

\subsection{Field Visit}

The researcher has visited several places, which are NACC (Noor Arfa Craft Complex) in Kuala Terengganu, National Textile Museum in Kuala Lumpur and Nysakapas in Kampung Serada, Kuala Terengganu. In January 2016, the first field visit was at the National Museum. Followed with a second field visit to NACC (Noor Arfa Craft Complex) was on November 2017 and also field visit to Nysakapas in Kampung Serada Kuala Terengganu, Terengganu. The researcher gained some information while conducted the field visit at the research site.

\subsection{Observation}

The first of before getting any data, an observation has been done to get data to this study, it is because the observation method provides a way of data collection and information to support this research. Moreover, observational data collection contributed to focusing 'natural' settings which allow the explanation of social processes and phenomena. In particular, they can facilitate understanding of what people do and how these can alter in response to situations over time, especially where people find their practice challenging to articulate. An observation method also helps this research to achieve specific goals which were discovered and verified. The purpose of the observation was to define and to inspect at selected batik workshops and Museums-the photographing at the research site. The remark was made on companies that are chosen by their expertise or background in batik making. However, observation is not just about visiting batik workshops, museums and galleries only but, the inspection was also executed to explore and compare traditional batik sarong through their process and designs. The observation was done to examine batik sarong from the researcher's collection of imitation batik sarong and analyse accordingly to the RQs, and ROs stated. 


\subsection{Interviews}

The interview was undergone with three participants involved in this study. The first participant that interview is the staff from Noor Arfa Craft Complex, the meeting was done on the 22nd of November 2017. The participant was chosen base on their background, knowledge and skills as well as a pioneer in making batik in Terengganu. The second participant was involved is Mrs Haniza Hashim, a contemporary batik artist and block artisan. Her background was from an architecture field, but she is showing her interest in batik after she moved to Kuala Terengganu and started to sell batik terap (batik block) on social media. The last participant is Mrs Rosidah Abdullah from Jabatan Muzium Negara (National Museum Department). Her knowledge of batik was extensive, and I managed to get a fruitful discussion with her. The supported tool was executed through recorded by voice recorder so that all the essential information can be played over and over again to extract the data collection.

\subsection{Findings}

In this section will discuss an overall overview of the emergence of imitation batik in Malaysia. This discussion will be divided into two parts, which is to study the type of imitation batik sarong, which includes their design and changes that related to the researcher's objective. The second section that related to this research objective is to analyse the selected design character of the imitation batik sarong in this country which is Malaysia. The researcher will begin to discuss the chosen design characteristic of imitation batik sarong in Malaysia, and it is motifs design. The researcher collected all of this output by field visiting, observation, and visual analysing. The discussion on visual interpreting will be based on the researcher's collection.

\subsection{Type of Imitation Batik Sarong}

Imitation batik sarong was known for its cheap and versatile designs. Despite being cheap, variations of the beautiful bright model that were imitated from other batik design countries, it is important to know how to identify and analyse when the first encounter of the imitation batik sarong. Though, to identify an imitation batik is not rocket science because ones can quickly identify and examine through characteristic. However, there crucial parts that need to be looked upon to. Apart from that, uncounted imitation batik can be found in places and shops lots. For instance, many shops are selling imitation batik sarong in the area of tourism spots such as Pekan Kuah Langkawi, Pasar Payang, Kuala Terengganu, Penang Street, and many other places for tourist spot attraction. The top attractions will be filled with tourist, and it is a chance for the seller to sell batik imitation at low prices. Most probably, the seller will claim that the batik is an authentic batik. The batik that is sold in tourist spots at lower prices is an imitation batik. Tourists believed that the batik is an authentic batik because they were not aesthetically aware of authentic batik characteristic. In contrast, authentic batik will cost from RM90 and can reach up to hundreds of Ringgits.

\subsection{The character of Imitation Batik Sarong}

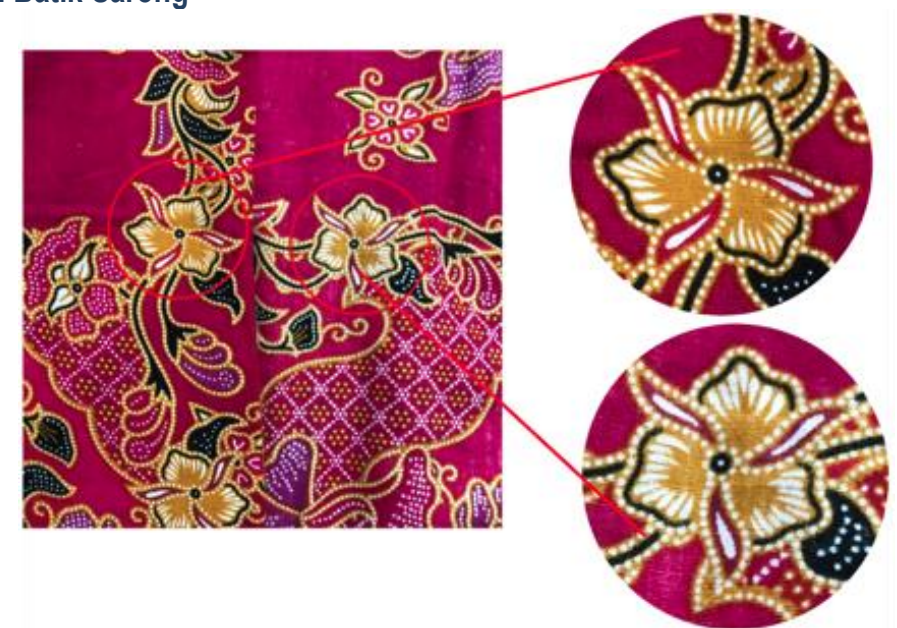

Figure 4.1 The pigmented differences of both surface on the imitation batik design.

The imitation batik sarong design is similar to some of the batik design from other countries. The layout of the design is seen with a particular characteristic. Other countries are trying to imitate and copy the design that defines cultural identity. The imitation of batik design is sometimes exported to other countries. Such as Indonesia, they shipped their imitation Javanese batik into Malaysia and Thailand, same as Thailand, they exported their imitation batik into Malaysia. Thailand imitation batik was usually, sold in the North of Malaysia. Typically, the differences between batik imitation from Java can differ from imitation batik that is made from Thailand. A Thailand made imitation batik sarong owns its pattern and design layout. For most of Thailand made, that are usually have flanking borders made up of the creeping flowers as well as the bamboo shoot that stood in vertical. These criteria have been found like in the researcher collection, which was shown in Figure 4.3. Furthermore, the other criteria are the most of the imitation batik sarong parts, especially in the badan kain (the body) covers with flowers. In this case, the imitation batik sarong in Figure 4.2 shows several gigantic flower bouquets. 


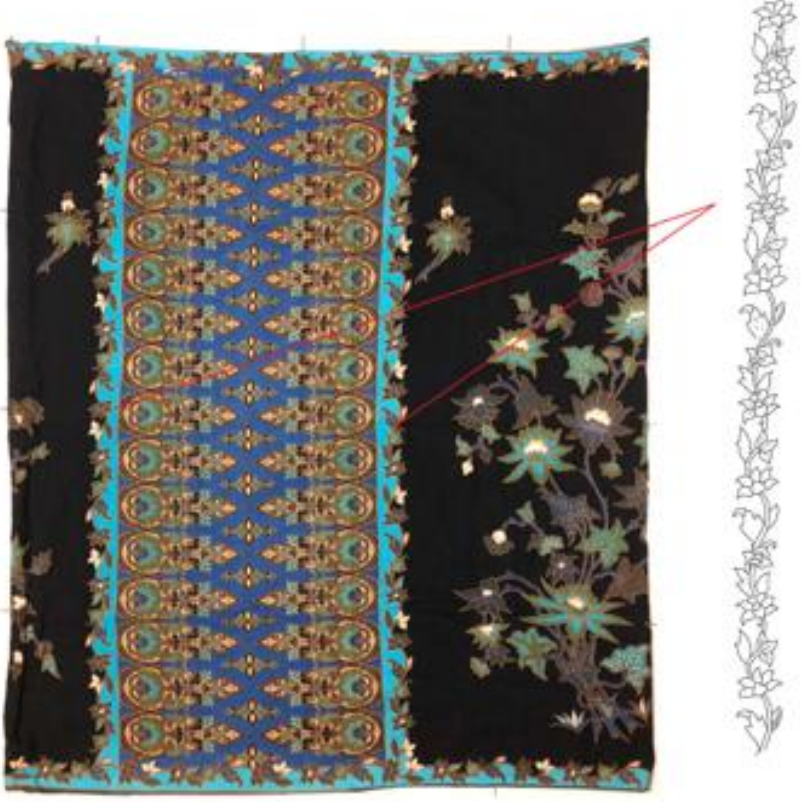

Figure 4.2 An example of Thailand made imitation batik sarong.

Apart from the characteristic matter, the design of imitation batik sarong, there are several values to look upon to, such as colours as stated in the literature review, which some colours are represented by culture and identities in traditional batik. For instance, Javanese batik has its colour code depending on their religion and region. Every design of colours does not simply copy each other. Despite all that, in imitation of batik sarong design, the batik was all about colours. The more the colours, the merrier the imitation batik can be produced. Because the availability of a variety of dye colours, the imitation batik producer can make it comes in a range. So, from that, a lot of beautiful colours imitation batik are produced. The imitation batik sarong applied a variety of colours include the bright to warm tones colours. They only use synthetic pigmented colours in imitation batik.

Furthermore, the dyes that are used in the imitation batik was a synthetic dye that can be added and subtract accordingly to the formulation. The dyes are not penetrated to the other surfaces. The apparent criteria of an imitation batik sarong design, the marks from the wax does not appear at the backsides of batik the sarong. Another aspect to look for in characters that appear in traditional or authentic batik is the "cracking" marks that are left by the wax resist. The wax will leave a retak seribu (crack mark) after hardening and were folds many times. These crack mark that imitated into imitation batik sarong look like the same as the authentic batik at first glance, but if we look closer, the imitation batik sarong that echoed the cracking mark by will display purposely scattered tiny strokes all over the batik imitation. However, the "cracking" marks are not an ultimate motif that appears in all batik. It is all depended on the batik maker themselves.

\subsection{Design and Layout}

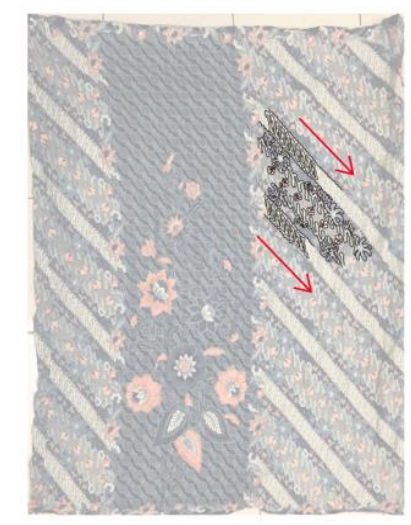

Figure 4.3 Diagonal pattern on the badan kain (the body).

The design layout is the arrangement of design on a specific surface. The design layout of the imitation batik is a placement or arrangement to fit accordingly in the structure of batik sarong. Designing a layout of batik sarong is not simple. Expertise is needed to 
make the design balance, and the proportion of motifs are fit in the sarong. The design layout that the imitation of batik sarong has varied, and it creates a strong composition. The layout mostly has what it takes as a sarong design structure. The design layout of the imitation batik was all symmetrical with each other. However, most of the imitation batik has a very sturdy design, which is not as lively as traditional batik. The example of imitation batik from the researcher's collection shows the model is placed in symmetrical and very neat. However, overall the designs are placed beautifully.

\subsection{Structure of Imitation Batik Sarong}

Few parts of batik sarongs are known for pengapit, kaki kain, kepala kain and badan kain. The batik sarong in Malaysia where the pengapit is placed parallel in at the edge of kain before they sew to make a hollow for sarongs. The badan kain (the body) is in the centre of the kain are mainly covered by motifs and designs. The imitation batik sarong from my collections was analysed; it can recognise a few parts that show the same structure as shown in Figure 4.1. The first most obvious is the kepala kain or head panel of the imitation batik, then there are badan kain or the body panel of the imitation batik sarong. The third is the pengapit kain or the flanking border around the kepala kain, lastly the tepi kain, or the edge border of the imitation sarong. As to identify the characteristic differences of imitation batik sarong in Malaysia was by an observation that was stated in Figure 4.2 and Figure 4.3. First, is the batik's body or badan batik sarong (body panel), which is horizontally located on the sarong. This body panel of the sarong is the major panel in a sarong. Second, is the kepala kain or the head panel. The head panel is consisting of a vertical standing rectangle with a design which differs from the body panel. The third part is the pengapit kain or flanked borders that appear to differentiate between the badan kain (the body) and the kepala kain (the head). Last but not least is the tepi kain or pinggir kain (the borders) that define the edge of the bottom and upper of the fabrics. All of the terms stated above are the essential part of traditional batik sarong.

Back

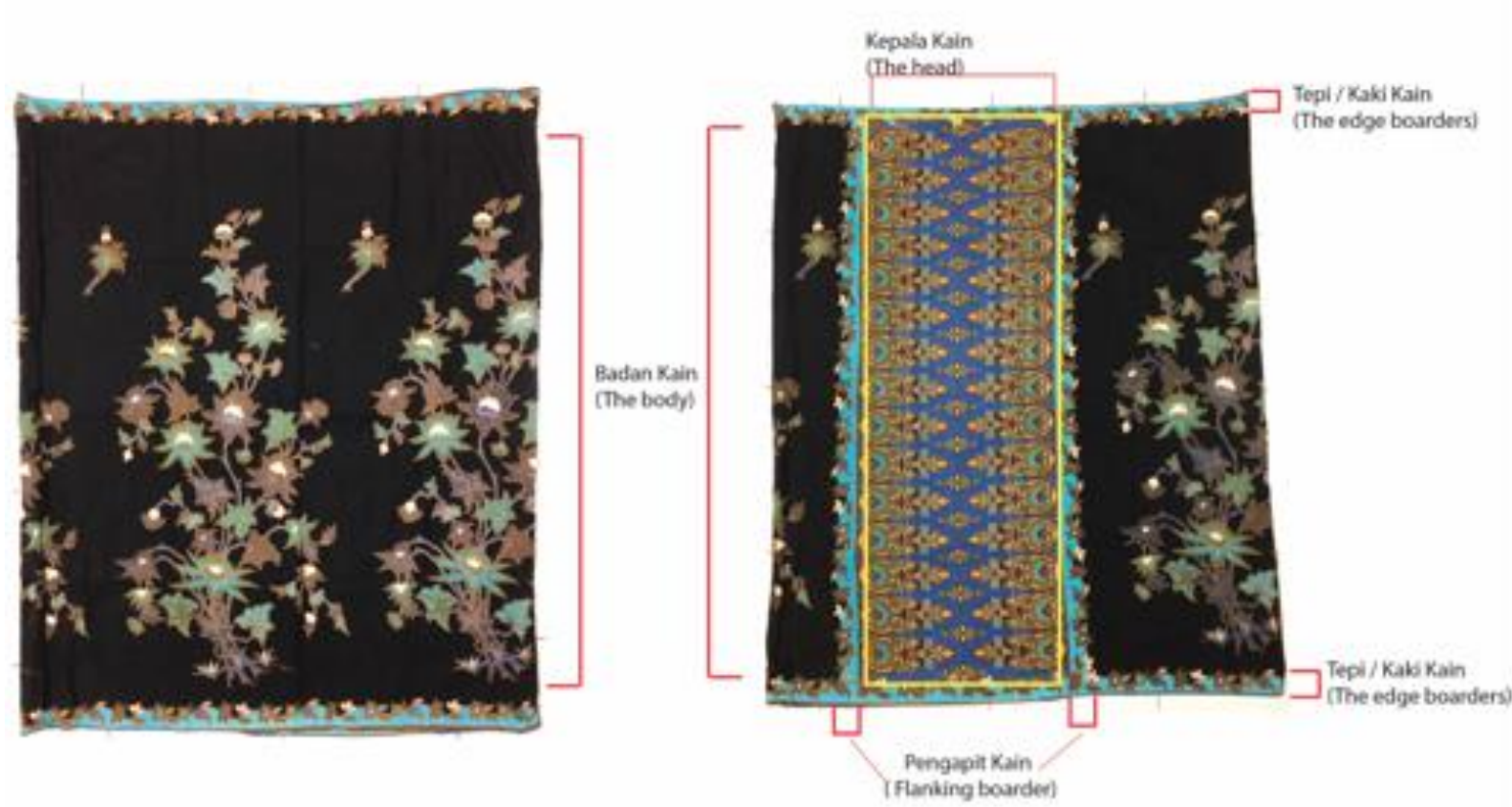

Front

Figure 4.4 Details of imitation of batik structure and its components.

The traditional structure can be found in almost batik sarong as well as in imitation batik sarong shown in Figure 4.4. However, in the sarong category, not all sarong distinct the same feature as the above characteristic. Some of the sarongs have a diagonal border in the centre, and some of the sarongs will not bother to have kepala kain in them. These are mostly featuring that are implemented in imitation batik. While batik Malaysia, they do not have certain features but the only basic and essential structure of batik sarong. There are three types of batik sarong which are, batik sarong canting (hand-drawn), cap (stamped or block) and batik sarong cetakan (screen printing).

\subsection{Technique and Technical}

The techniques and process are a massive difference in making these batik sarongs. The main primary tradition of making batik is using the wax resisting-the batik canting (hand-drawn) involved in the process of drawing. The hot wax put in the canting (a stylus 
pen-like and a reservoir that contains the wax) and then draw a motif on the plain cloth. The batik cop (stamped or block) is where the block of design made from metals material as a completed block. Then to transfer the design, the metal block needs to be dipped into melted wax and stamp onto fabrics. The design of the batik sarong shows the result of high skill and creativity of the batik makers in arranging the essential batik structure. The basic figure shown in Figure 4.5 is applied to all batik in Malaysia that included batik baba nyonya, Kelantan and Terengganu. The difference is only on the design and motifs that are used in these types of batik.

Besides of different physical appearance design and material, the techniques also have to count in. The usage of synthetic dyes that were from printing ink produces a very unpleasant odour. The synthetic dyes are made from chemicals to achieve a variety of colours. Unlike traditional or authentic batik that went through wax resist will serves the smells of wax that still adhere to the fabrics. If look closely and analyse the material and the design that are on the fabric. In another characteristic is the usage of the colours shown in imitation batik that are slightly stiff and rigid. The stiffness is because of the overlapping colours on top of each other. Unlike authentic or traditional batik, the colours were not overlapping on top of each other; this is because the resisting wax techniques that instantly create a harmonious design. However, the making of imitation batik and its process is unknown. However, through the findings, it can be assumed that this imitation batik design process is involving machinery and printing.

\subsection{Design of Imitation Batik Sarong}

Batik motifs in Malaysia are based on nature, particularly plants or florals. The Malay people are surrounded by nature, especially in their kampung (village or hometown). Up until today, there are few remotes and village area are still 'green' and untouched by concrete, especially in the north of Malaysia. A human adopts the florals into their fabric design because they live in an environment full of natural. However, the adaptation of fauna and geometrical was found in the batik motifs. The same batik traditional Malaysia is adapted from nature which is a flower. However, there are times that the batik artist implements the fauna in the batik sarong with incomplete parts due to the prohibition of Islam in Malaysia. The batik sarong and the batik imitation are quite similar at just one glance.

\subsection{Floral and Vegetal Motif}

Pleomorphic or Phyllo morphosis means the variation of leaves, botanic which are a synonym to flora that is usually present in batik. Flora in batik as the symbol of aesthetic to make the batik appear more beautiful for the wearers. The flora design in batik block appears as a repetition on a specific side of batik structure. On the other hand, Malaysia's tropical location provides an abundance of plants. The Malay people have exploited the medicinal properties of these plants. They have successfully used all parts of plants: the flowers, roots, leaves, fruits, bark and even seeds. These are because in the old days, Malay people live in a village used to surrounded by nature and they adapt what they see in their work or fabrics. It is also known that the adoption has an intrinsic meaning such as the benefits and nutrition from particular floral or vegetal.

Nevertheless, imitation batik design is also imitated from the same design, and sometimes they were stylised. Some of the imitation design was derived from blooming flowers that have many petals, such as Roses, Sunflowers, Hibiscus, bunga cempaka (magnolia champaca) and bunga pecah lima (five petals flower.) Apart from the flowers, there are vegetal motifs that are applied in imitation batiks, such as Yam leaves (caladium), water spinach and other vegetal design.

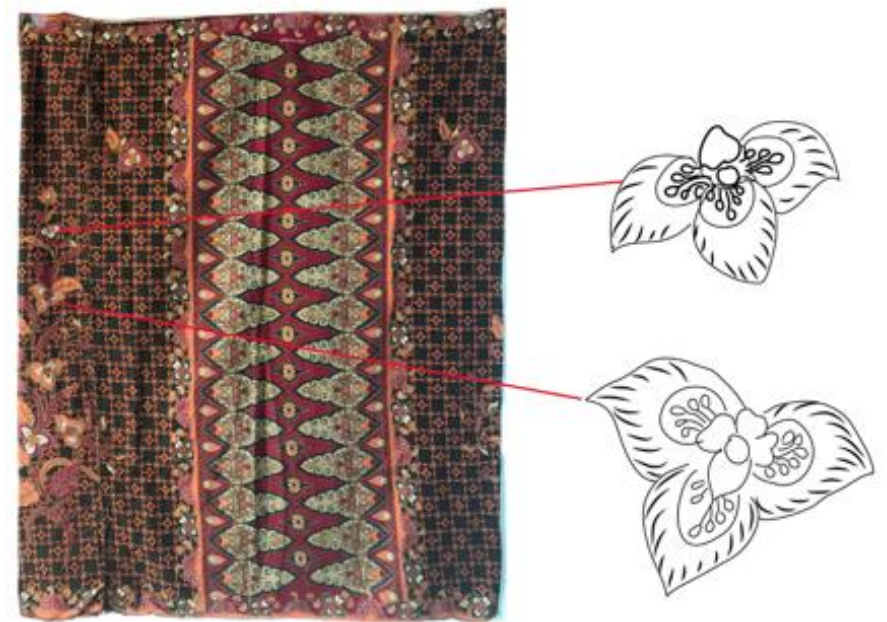

Figure 4.5 A Slipper Orchids a unique flower.

After looking into the design of flower that appears on the surface of imitation batik in Figure 4.5 show very similar flowers to the Slipper Orchids, the morphology and characteristic of Slipper Orchids are usually formed of three petals and three buds together with their anther. Slipper Orchids are rare and unique flowers, and it is said to be the mystical flowers that are different from other flowers and grown under trees, prairie and meadows. To grow orchids are sometimes challenging because they need an intensive and full of care as they grow amid a tropical jungle. 

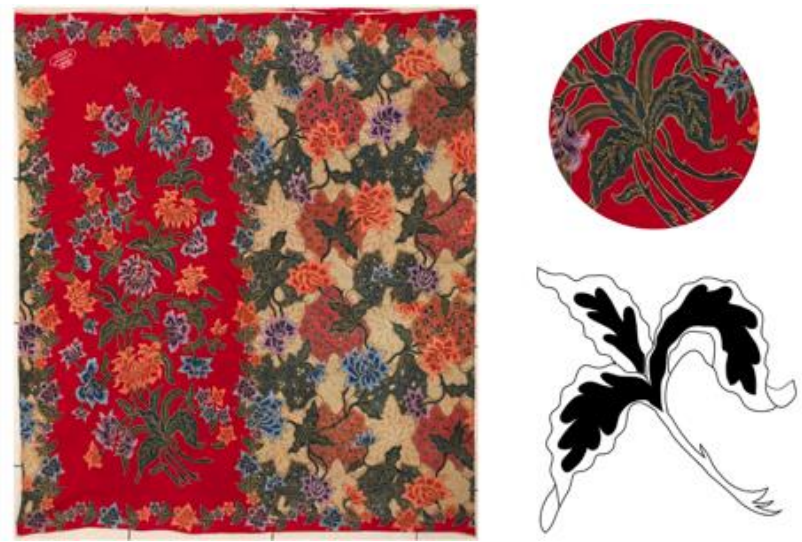

Figure 4.6 Water Spinach or Kangkung.

\subsection{Fauna Motif Design}

Fauna motifs are motifs of animals that are commonly used in batik sarong whether in batik block, canting or silkscreen batik. Fauna also found in imitation batik sarong and kain panjang (long cloth) from Indonesia. Several other countries have the same application of animals in their fabrics. The implement of animals or fauna in fabrics defines the identity of a community. These are because of wanted to portray their belief in describing and glorify in what they believe. Sometimes, the depicting of animals in fabrics were related to promoting tourism in certain places. Example in Terengganu, sometimes batik was found full of sea turtle portrayed on the batik. That is because sea turtles are very famous in Terengganu, and Terengganu was elected as the sea turtle sanctuary.
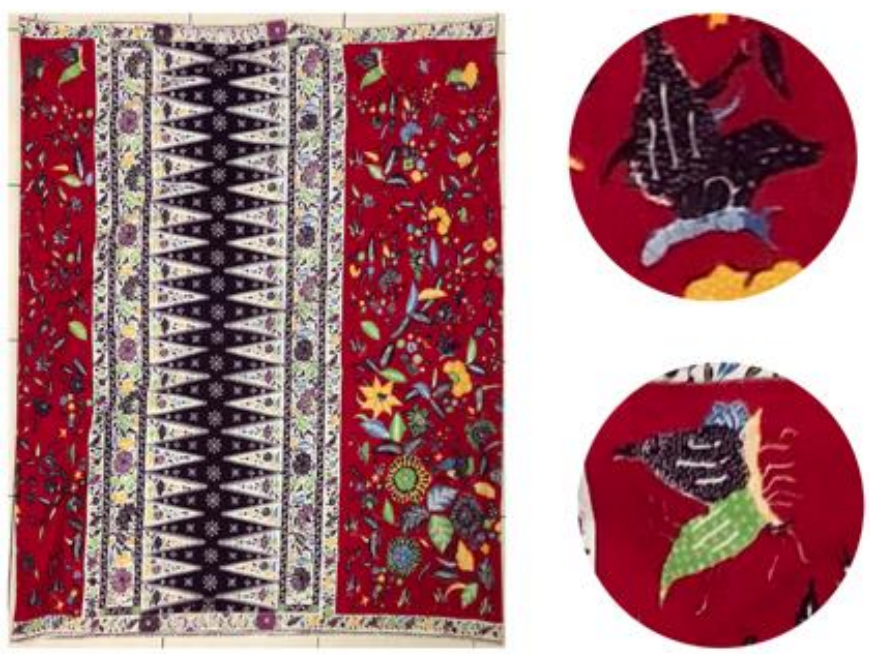

Figure 4.7 Butterflies depicted on the imitation batik sarong.

In Figure 4.7 shows an imitation of Batik Sarong that has several butterflies' motifs. The species of butterflies are unknown as Islam prohibited the usage of animals and symbolic in any decoration or households. However, in this case, the butterflies are also implied in the imitation batik sarong. The portraying butterflies in imitation batik sarong are defined as the beautiful creature that is very synonym with flowers. Butterflies are known to be involved in pollination of seeds and buds of flowers. The butterflies are portraying of beauty because butterflies have variants of colours and pattern on their wings. In Figure 4.28 shown two butterflies that were implied in the imitation batik sarong. In observation, there was also an unknown small animal that was perceived as insects or beetles. Beetles are also known as the insects that live nearby between flowers and plants.

\subsection{Conclusions}

To sum up, this study discussed the characteristic of imitation batik sarong design in this country. The emergence of batik imitation is a severe issue in Malaysia as they kill batik industries, especially on the East coast of Malaysia. With the overflowing of mass production, produced cheaper than authentic batik has won customers' heart who are not aware of batik aesthetically values in buying decision because of the design that is same as authentic batik. People should aware and know how to examine and look for genuine batik base not only the price but on the quality. As a result, the findings presented that imitation batik has become much more similar 
to traditional batik as they learn to adapt and mimicry the design and wax stain. However, as a whole, the imitation batik sarong design is different from the traditional batik sarong in term of their originality and character.

\section{Acknowledgement}

We would like to acknowledge to the Universiti Teknologi MARA under grant No. 600-IRMI/MYRA 5/3/REI (002/2018) and to everyone who was cooperated for this study.

\section{References}

Arney, S. (1987). Malaysian batik: creating new traditions. Kraftangan Malaysia.

Djoemema, N. (1999). Regional Variations in Judi Achdi. 1999. Batik Spirit of Indonesia (pp. 38). Indonesia. Yayasan Indonesia.

Elliott, I. M. (2013). Batik: fabled cloth of Java. Tuttle Publishing.

Fong, J. \& Youwen, L. (2016). Screen Printing. Issue 6. National Library Board, Singapore.

Hussin, H. (2006). Aktiviti Seni dan Budaya Lampau: Penghasilan dan Penggunaan Tekstil di Alam Melayu Dari Sudut Sejarah Silam. Jebat, $33,96$.

Jumin, A., \& Samah, A. (1985). Mengenali batik dan batik tiruan.

Legino, R. (2012). Malaysian Batik Sarongs: A Study of Tradition and Change.

Legino, R., Sajar, N., Nawawi, N. M., Kamaruzaman, M. F., \& Ba'ai, N. M. (2017). Malaysian Batik Sarong Layout Design. Advanced Science Letters, 23(11), 1072610728.

Lukman, C. C., Amir, P. Y., \& Sunarto, P. (2013). Kebaya Encim as the Phenomenon of Mimicry in East Indies Dutch Colonial Culture. Arts and Design Studies, 13, 1522

Luzar, L. C. (2010). Kreasi Cetak Sablon Mudah dan Berkualitas Tinggi pada Kaos. Humaniora, 1(2), 778-791.

Siswandi, R. (1999). The Roots of Tradition in Judi Achdi, Batik Spirit of Indonesia (pp.20). Indonesia. Yayasan Batik Indonesia.

Steelyana, W. (2012). Batik, a beautiful cultural heritage that preserve culture and support economic development in Indonesia. Business Review, 3(1), 116. 